\title{
Transcending the Eurocentric Development \\ Paradigms in Nigeria: \\ The Traditional Age Grades in Discourse
}

\author{
Ernest Osas Ugiagbe* and Ijeoma Ugiagbe \\ University of Benin \\ Benin-City, Nigeria
}

Received 24.12.2014, received in revised form 10.02.2015, accepted 22.02.2015

The quest for sustainable grassroots' development by Nigerian government calls for the need to look inwards and re-examine and evaluates our indigenous cultural practices in an attempts to attain the desired development goal. This paper evaluates the indigenous age grade systems in Nigerian societies, and how the traits of the age grades can be harnessed for the attainment of the much desired sustainable development in Nigeria. It argues that the cultural bond and unity of purpose between the members of the age grades a priori make them a veritable tool for transformation of the rural areas. This is because the age grades know their communities more than out-siders and the so-called developers, hence what needs to be done is to empower the various age grades and give them the necessary tools and technical know-how. The development of the rural areas will gradually but surely become a reality in the near future.

Keywords: Grassroots development, cultural heritage, age grade, community, empowerment.

Research area: sociology.

\section{Introduction}

Every human society aspires for a better wellbeing and this accounts for the constant renewal of its livelihood tools and methods. Cultural elements are borrowed from one culture to regenerate another. Anthropologists and development professionals have pondered over time through theories on how, why and with what consequences do these changes called development occur. The concept of development was developed to design a positive change (progress) in a society. Its definition differed according to school of thought. In
1982, UNESCO produced a generally accepted definition of development:

Development is a complex, holistic and multi-dimensional process which goes beyond mere economic growth and integrates all the dimensions of life and all the energies of a community; all of whose numbers must share in the benefits that result therefrom. The principle is therefore proposed that development must be founded on the will of each society and express its profound identity (UNESCO 1982).

\footnotetext{
(C) Siberian Federal University. All rights reserved

* Corresponding author E-mail address: ernestugiagbe@yahoo.com, ijeomaugiagbe@yahoo.com
} 
Nevertheless the Euro-American model of development based on economic growth is still in vogue and remains very attractive.

It is this vein that third world nations (including Nigeria) have been striving to attain the Western level of development engaging their finances into great projects which gave birth to white elephants projects and waste. By the mid-1980s, most African countries were under Structural Adjustment Programmes initiated by the World Bank. Sub-Saharan Africa then went through grave economic crisis whose effects shattered different sectors of its economies notably agriculture, industry, services, finances and transport amongst others. Evidence from the literature reveals that many United Nations resolutions and developmental targets had remained elusive while some important projects and programmes are either unimplemented or they would not yield the anticipated outcomes (Onaolapo and Oladejo, 2011). The Nigerian situation represents a developmental experience characterized by poverty. With a population of about 176 million (CIA Fact book, 2013), and GDP per capita of $\$ 641$ (2006), two-thirds of Nigeria's people are poor; Nigeria has the third highest number of poor people in the world (Alabi et al, 2007).

The formal structures of government in Nigeria have increasingly become a fiction in governance and a mirage in reaching the desired Eldorado. This is because the services they provide have declined sharply in quality and quantity. In several respects, these services are no longer being delivered by government agencies - either because of longer and endemic industrial conflicts arising from workers' protests at their poor pay or because of the lack of essential equipment in important sectors like education, health, security amongst others, or the loss or absence of the culture of public service. Poor quality service or absence of service and failure to bring about sustained progress in socioeconomic development of Nigeria after over a century of contact with colonial masters and half a century of independence has to attempt at providing for alternative institutional development structures that will improve essential services in terms of security, improvement/maintenance of roads and bring about sustainable grassroots' development in Nigeria (Olowu and Erero, 2010).

The failure of governmental structures inherited from the colonial state in Africa, has stimulated renewed interest in indigenous knowledge and institutions in recent years (Ake, 1990; Sawyer, 1993; Davidson, 1992). This renewed interest is based partly on the fact that they are more effectively institutionalized and relied more upon by African people to provide them with required goods, services and development of their communities in the face of the failure of the formal, colonial based structures. However, there is the recognition that African indigenous institutions also have their weaknesses - their small scale, dealing with heterogeneity and particularity, digesting and processing information and change from external formal institutions and then external context (World Bank, 1992).

The need to look inwards into our cultural heritage to attain grassroots development becomes imperative. The need to evaluate indigenous agencies as an alternative development strategy becomes necessary since the formal AngloAmerican models of development fail to extricate Nigerians from the grip of the vicious circle of poverty. The traditional agencies are fundamental to the existence of human societies. In Nigeria and indeed most of African countries age grades are playing important roles in development, through the mobilization of their members to form development unions and umbrella organizations for socioeconomic transformation of their 
communities and by implication the society in general (Aver, 2012).

This paper examines the traditional age grade organizations in the Nigerian society with a special a focus on Benin age grade systems as an alternative grassroots' development agency. The paper specifically examines the special traits, principles and aspirations of age grade systems and organization and tries to establish the nexus between such unique traits as a feasible panacea to the development problems and impediments in Nigeria. The paper also explores the role of age grades in traditional societies and contextualizes their importance in the quest for sustainable socioeconomic development of Nigeria

\section{Conceptual Clarification/ Theoretical Orientation}

The case for promoting developmental status in Africa largely rests on the inability of previous development approaches to help Africa diversify and transform its economies, generate steady and sustained high growth rates or deliver adequate levels of social development. Development in Nigeria is constructed around a government with the political will and legitimacy to perform specified developmental functions, a professional bureaucracy that implements, established national development strategies and policies, and interactive mechanism allowing stakeholder groups to be involved in designing and carrying out development polices. In Nigeria these systems are fashioned after the Westminster model, and have failed to bring about the much desired sustainable grassroots development like the Asian Tigers (Economic Report on Africa, 2011). Ideally, development states effectiveness in promoting economic transformation derives from its ability to promote more equitable and efficient resource allocation, monitoring, its capacity to design and carry out policy as well as its closer coordination of institutions.

The underdevelopment woes, poverty and retrogression in Nigeria are partly attributed to leadership failure. That is, Nigeria has lacked a visionary political leadership that is committed to national development goals, and one who can motivate and guide the planning process. Second is the problem of incompetent and corrupt bureaucracy which has failed to use its autonomy and power to implement the programme and respond swiftly to rapidly changing local and global conditions. Since the Westminster model of governance and development orientations has failed to transform Nigeria socioeconomically in all ramifications, it calls for the need to assess our indigenous cultural heritage.

Western development models and approaches often prove less effective when transplanted elsewhere; hence every nation, culture and setting is rooted in its contextual value system and culture (Ahiazu, 1991; Adeleye, 2011; Zoogah, 2009). This underscores the existence of African indigenous styles of development which have their roots in African culture. In Nigeria the indigenous people had their own management and development approaches, philosophies and practices prior to the advent of colonialism and they were able to survive a very tortuous post-slavery era, colonialism, brutal economic exploitation and attempted cultural annihilation through these philosophies and strategies (Muo and Oghojiafor, 2012). Some African scholars and authors have advocated the integration of African traditional practices and structural ordering with the strength of the scientific and rational approaches of the Anglo-American development strategies and philosophies.

Otite and Ogionwo (2001) define age grade as a group of people who are roughly of the same age. Similarly Ikechukwu (1992) also posited that age grades are groups of persons who according 
to the societal norms and value are regarded as people of the same age. According to him, age grades vary from one community to the other. In some communities, persons within a specific period of three, four or five years usually form an age grade. But each age grade is clearly distinguished from one another.

In many African societies, there exist such institutions as age grades which the Igbos called (Otu Ogbo) and the Benin called it Otu Igbama ( Edion, Eghele and Ikpolughe, and Ikhuevbo ). The age grade is made up of people within the same age bracket usually within three to five years from each other and is a means of creating peer groups, foster unity and responsibility, acting mainly as a socio-cultural institution (Wadjaja, 2001). The Igbos of Eastern Nigeria, for example, has a culture of segmenting into different age grades which can be likened to teams in management and platoons in war games. Among the members of these different age grades can be found members with different roles which fit into the description of age grades of being teams. As years pass by, the younger groups ascend the ladder and take over the roles of older grades. Age grade serves as avenues for social interaction among members and agents of development. Usually there is a competition between age grades in terms of development projects they sponsor or execute in their various communities (Ifechukwu, 2010).

In the pre-colonial period, the newly formed age grades had to prove themselves for maturity by defending the community against hostile neighbours or enemies (Widjaja, 2001). The newly formed group can only be accepted to adulthood and honoured with a name if she performs her task meaningfully with success. Among the Igbos, a newly initiated age grade is expected to choose a well-respected elder who performs leadership role for the group by facilitating the recognition of the group among elders (Oghojafor et al, 2013).
Age grade is a form of social organization based on age within a series of such categories through which individuals pass over the course of their lives. The number of age classes/ grades, the determining factor and ages, and the terminology vary significantly between traditions and ethnic groups. In tribal societies entry into an age grade - generally gender separated - is often marked by an initiation rite which may be the crowning of a long and complex preparation, sometimes in retreat. After a period of years, during which they often perform certain common activities, alone or under senior guidance, members may be initiated either collectively or individually into a more senior age grade (Benardi, 1985).

Similarly, Egharevba, (1978), writes that with respect to age, one finds that in most African societies, successive cohorts within, say, a 3-year span are grouped together and regarded as age grades sets. Each age grade is given a special name that helps to define its position in the society relative to other age grades. Members of each age grade are meant to know one another fairly well, to choose leadership group among their members, to meet to discuss issues of mutual or communal interest, and to be willing to help one another and defend the community when the need arises.

In addition to the integrative and regulatory functions of systems of age grouping for a society as a whole - such as social training, defence and government, they also have internal functions for their members irrespective of their relation to outside groups. Among age mates or members of the same age set, there is usually a strong bond, and age sets serve in some respects as mutual aid and societies for their members (Ottenberg \& Ottenberg, 1960). In this paper, age grade is conceptualized as a group of people in a society who are of the both sex and approximately the same age having certain definite duties and 
privileges in common and constituting a division of a tribe, society or ethnic group. Age grade sets type of solidarity of non-residential groups that cut across kinship ties and this promotes broader solidarity of young vibrant men who are usually cooperates in secret ritual or craft performances together. Individuals generally remain closely associated with their age grades throughout their life to be part of this association (Aver, 2012).

Age grades play traditional roles in our traditional societies and many of these roles survive the onslaught of modernization, industrialization and urbanization. Some of these roles include: ensuring unity among its members. Among the Igbos, unity and cooperation are very crucial to their leadership style and societal progress. African leadership is ruled by respect for the dignity of others: group solidarity (an injury to one is injury to all), team work (none of us is greater than all of us), service to others in the spirit of harmony, independence (each one of us needs all of us). It is widely believed that the Igbo world like other ethnic groups in Nigeria is an integrated one in which all created beings, the living and the dead are in communion through symbolic interaction and other communication channels. The spirit of oneness is not tilted to the nuclear family; it extends beyond the group from the same ancestral tree to a clan, village or town. The individual is not alone in the world; he is surrounded by members of his community. The age grades at all levels ensure that the Espirit De Corps which is Igwe bu ike (unity is strength) is maintained and jealously guarded (Oghojafor et al, 2013).

Co-prosperity: African culture stresses relationship or kinship. An African tends to see mankind as members of the same community; hence the extended family is widespread in African continent. The age grades and other social norms ensure that each person should be his or her brothers'/sisters' keeper, a case of one for all, all for one. The age grades ensure that the concept of Onye Aghala Nwanne Ya is strictly upheld all the time. Among the Benin, the concept of Akugbe ore' etin also ensures that the members of the society through their age grades are united and have the spirit of oneness. The social solidarity is aptly described as mechanical social solidarity (Giddens, 2009).

Age grades are charged with maintaining security of live and property in African society. Okafor (2007), posited that in traditional African society's security maintenance, crime prevention, and general law enforcement were based on each society's historical circumstance and desire. Thus, most members of each society wilfully partake in programmes and activities aimed at preventing and controlling criminality. Age grades and other community members, individually and collectively, play roles in crime control in each society. Each age grade has its methods and procedures for security maintenance crime prevention, and general law enforcement. According to Aver (2012) 'one of the main reasons for the wide acceptance and celebration of the age grade methods and procedures is that citizens tend to know their society's control justice and law personnel well. Citizens of the age grade have reasonable knowledge of each office holder and that of their members moral, values, ethics, excesses and limitations. Age grade members have direct and indirect link to the people, and so influence their control, justice and law personnel.

The age grades are very effective in the maintenance of law and order because they are usually a very organized group which shares a common ideology and whose activities are centred on set goals, beliefs and dogma which regulate their conduct. Igbo (2006) stated that age grade guards its name and reputation jealously hence each grade takes all the necessary actions to make sure that its members live up to 
the community expectations. The age grades settle disputes between their members and punish erring members who engage in acts inimical to their reputation and ideology.

\section{Age Grade as Alternative \\ Sustainable Alternative \\ to Grassroots Development in Nigeria}

One of the major development challenges facing the governments at the three tier levels (Federal, States and Local Government Areas) in Nigeria is the increasing disparity between the urban and rural areas. This gap according to Igboeti (1992) has its roots in the neo-classical economic theories which presumed that development can be accelerated by concentrating investments in the cities and that rural poverty will be ameliorated by the trickle down of benefits from the urban industrial growth. This has resulted in imbalance between the urban dwellers and rural people in terms of living condition and infrastructure. Consequently, there is the search for alternative strategy that will not only accelerate growth but also spread the benefits of development to the rural areas.

Aboyade (1980) has specifically decried the profound dualism between the urban and rural areas of Nigeria and the proportionate costs and consequences of rural infrastructural lay behind urban modernism. Similarly, Muoghalu (1992) contended that rural development has become a national imperative in Nigeria and gave reasons for his position. He argued that the proportion of the national population resident in the rural areas of Nigeria is high, for example it was $80.7 \%$ in 1963 census, $70.113 \%$ in 1985 and $69 \%$ in 1990 . The gap between rural and urban is a threat to sociopolitical stability in Nigeria. The unfortunate situation of this dichotomy results in pervasive and endemic poverty, squalour, poor health linger and lack of access to formal education amongst others (Akpomuvie, 2010; Okafor, 2005).
The position of this paper is that rural areas of Nigeria are on toss [to borrow Okafor's (2005) coinage] because of the so-called trickle-down effect development policy coupled with dearth of knowledge about rural societies and what they actually need in term of development. The socalled development experts and bureaucrats have little or no knowledge about the problems and prospects of rural areas. This has resulted in the ill-fated programmes and white elephant projects purportedly earmarked for rural areas that failed woefully to transform the rural areas and the lives of the rural dwellers. The missing link is the inadequate knowledge about the rural areas. The nexus between the situation and condition of rural areas and where they ought to be is the people themselves. Progress and development will only be attained if the people (rural dwellers) are made to be part and parcel of development plans, policies and programmes.

The most outstanding stakeholders in rural areas are the indigenes and community members themselves. When rural dwellers are committed to their own destiny in terms of development, then there will be progress. The most pathetic but avoidable problem of rural areas is the so-called lack of maintenance culture. In other words, the feeling of ownlessness of the projects and infrastructures always results in rot and decay of infrastructures and by implication retrogression in the rural areas.

The age grades hold the key to development of rural areas because of the following reasons:

- Age grades know their terrain, their desires and prospects. The social solidarity between and within age grades will spur them on to ensure that programmes and projects attain their set goals and protected from vandals.

The service approach to community development calls for the active participation and initiative of the local people. The various 
age grades will form the hub of the management of any project in that community. The issue of unhealthy competition and wanton destruction occasioned by rivalry will be lacking. This is because age grades are hierarchical and leadership positions are well established hence the feeling of oneness will enhance development ventures.

It is the position of this paper that if the natural resources available in each community are harnessed through the empowerment of the locals - age grades, the much desired development will be attained in no distant time. For example, if the youths in rocky areas are empowered to start a quarry and stone cracking business, there will not be a high unemployment rate in states like Edo, Kogi, Enugu, Benue and most of the northern states. The south-south states will in the next 100 (one hundred) years depend on the granites and other building materials for construction. The Middle Belt and other northern states will also depend on the south-south states for timber, palm oil, and other cash crops like cocoa and rubber for their industries. The age grades know these products/resources more than others. The land will not be an issue because lands are owned by communities. The quarries and other companies in extrusion, processing, etc. are unfortunately in the hands of foreigners from outside Nigeria or outside the community hence the problem of capital flight will always continue to affect the communities adversely for a long time to come except the trend is reversed.

Age grades are metamorphosing into pseudo political and economic development associations (informal indigenous institution) such as community development association, youth organizations, trade and professional guilds, women group, social clubs, thrift and credit cooperative unions. These associations of age grade in modern times are credited with embarking on laudable projects like building of schools, health centres, and construction of roads, bridges, town halls and more importantly mobilization for community projects for the benefit of all. The government and development agencies should zero in on this natural, formidable and sustainable cultural heritage. The government should avoid rhetoric and face reality by empowering these community age grades across Nigeria.

Empowerment is a multi-level construct consistingofpracticalapproachesandapplications, social action processes, and individual and collective outcomes. In the broadest sense, empowerment refers to individuals, families, organizations, and communities gaining control and mastering, within the social, economic, and political contexts of their lives, in order to improve equity and quality of life (Zimmerman, 2000). Critical empowerment which is advocated for in this paper involves multi processes through which individuals and communities became emancipated from conscious or unconscious constraints and engage in negotiated actions to build community life (Ray, 1992).

Indigenous institutions (age grades) play active roles in the administration of justice, maintenance of law and order, peace keeping, provision of security and conflict resolution as earlier mentioned. These are some of the parameters that are used to measure development. If there are peace, employment and basic infrastructure in rural areas, the ruralurban drift will be stemmed. The winner-takeit-all that characterizes the political arena and government of Nigeria can be redressed if people are answerable to their community. Only very few Nigerians will defile their community and age directives or attempt offending or violating the rules of the gods and ancestral spirits or shrines of their community because they know the repercussion and the grave consequences. 
Diagrammatic illustrations of functions of age grades in Nigerian rural Societies

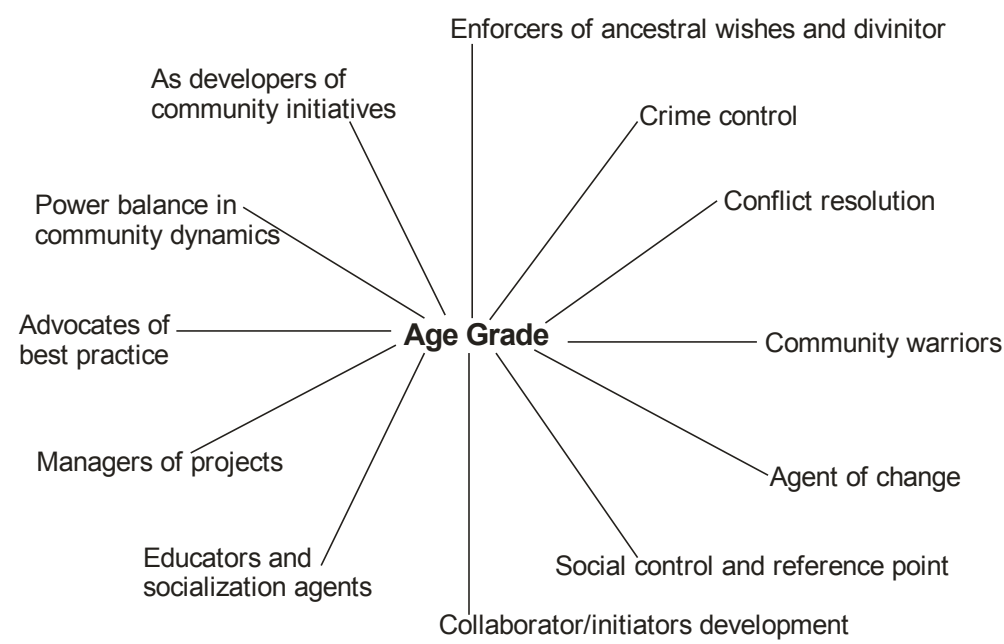

Source: The authors, 2014

But when an individual is elected or selected to lord it over many communities in the name of local government area chairman, then you expect- corruption and looting with reckless abandon.

The decentralization of administration by completely phasing our local government areas and replacing them with community development councils will be the antidote and feasible development alternative to the rot, decay and retrogression in the rural areas of Nigeria.

\section{Implication for Policy Development}

The import of this discourse is that all hope is not lost in Nigeria's quest for sustainable development. Just like the Asian Tigers looked inwards and evolved indigenous development paradigm that is being emulated all over the world, Nigeria should also re-evaluate some of her indigenous cultural practices to develop the Nigerian society and stem the tide of rot and decay that characterize our society.

Policy wise, this can be feasible if the relevant government and stakeholders can initiate and formulate policies that will put the rural development in a front burner. Policy should be formulated that will compel the state and federal governments to commit at least $20 \%$ of their budgets and also float a consolidated fund solely for community development. The government should train community leaders especially the youths on entrepreneurship, leadership and management. The aim is to prepare the age grades that may lack management acumen but with enough natural resources in their domain to transform their communities. The transformation of the communities will ultimately transform Nigeria in all ramifications.

Law should be promulgated to give such policies and initiatives a full backing. This will bring about healthy competitions between communities and not between geopolitical zones or between ethnic groups. We believe this is the best alternative for grassroots sustainable development in Nigeria.

\section{Recommendations}

We make the following recommendations in order to enhance the productivity of age grades in community development in Nigeria. 
- As a matter of national issue, there should be a concrete policy that will empower all age grades in Nigeria. This can be attained by devoting about 2 to 5 per cent of the national budgets allocation to communities instead of the conduit pipe draining the national wealth in the name of Local Government Areas allocation. Allocating money to community will enhance even and sustainable grassroots development in Nigeria.

- Social workers should reposition themselves not as the agent of endless topdown government initiatives but as those working more explicitly with and for the excluded and deprived, that is, to find an appropriate and critical political distance from a position of being merely agents of change driven by government objectives (Craig, 2002). This means that social workers should radicalise the profession through aggressive advocacy and politicization of community development. Aggressive and comprehensive allembracing advocacy for community development will yield the much needed panacea for sustainable development.

- Social work can also make important contributions to grassroots development through commitment to their research agenda aimed at evaluating the status quo ante of communities lived experience in Nigeria and specific development projects, programmes and policies that will bring about sustainable grassroots development

\section{Conclusion}

Despite decades of concerted efforts by both Nigerian government at all levels and the international development agencies to transform and develop rural areas in Nigeria, today the rural areas and communities still remain backward and a beehive of poverty. The failure to address the rot and decay in rural areas is partly caused by the lack of knowledge about the real situations in rural areas in terms of problems, prospects and the needs of the rural dwellers. The vision of grassroots organizations all over the world is to initiate and sustain development. The most natural, traditional and indigenous grassroots organizations all over Nigeria are the age grades. The age grades stand as a strong alternative and critique of ineffective models of development that have failed to deliver on the goals of transforming the rural communities all over Nigeria.

The vision and work of grassroots organization age grade will demonstrate a serious commitment to ending inequality and unending disparity between the urban centres and rural areas of Nigeria. All that is needed is a consolidated fund and budgetary allocation to community and attracting investors and other empowerment programme to the various communities all over Nigeria. This will not only kick-start grassroots development, it will also sustain gradual development that will ultimately transform Nigeria within a few decades.

\section{References}

1. Aboyade, O. (1980). Nigerian Public Enterprises as an Organizational Dilemma in Colins P. (ed) Administration for Development in Nigeria. Lagos. Africa Educational Press.

2. Adeleye, T. (2011). Theorising human resource management in Africa: Beyond cultural relativism. African Journal of Business Management 5(6) 2028-2039.

3. Ahiauzu, A. (1999). The African Industrial Man. Port Harcourt: CIMRAT Publications. 
4. Akpomuvie, O.B. (2010). Self-Help as a Strategy for Rural Development in Nigeria: A Bottom-up Approach. Journal of Alternative Perspectives in the Social Sciences Vol 2 No 1, 88-111.

5. Alabi, Josphua; Alabi, G., Ahiawodi (2002). Effect of Susu: A traditional micro finance mechanism on the organised and non-organised micro and small enterprises (MSEs) in Ghana. African Journal of Business Management Vol 1(8) pp. 201-208 No 11, 2007. http//www.academijournals.orgs/ AJBM.

6. Aver, T.T. (2012). The Role of Age Grade in Crime Control in TIV Society of Central Nigeria. Journal of Social Science and Public Policy. Vol 4 No 1 46-53.

7. Bernardi, B. (1985). Age Class System. Social Institutions and Politics Based on Age. Cambridge University Press.

8. CIA Fact Book (2013) 'The World Fact Book', available online at: https.//www.cia.gov/library/ world.fact publications/the-book/-cached (accessed 16 August 2013).

9. Economic Report on Africa (2011). Governing development in Africa - the role of the state in economic transformation. Economic Commission for Africa Publications, Addis Ababa.

10. Ifechukwu, J.A.O. (2010). An African solution to ASUU - Government dispute. Guardian Newspaper, $19^{\text {th }}$ Nov. pp 52.

11. Igbo, E.M. (2006). Criminology: A Basic Introduction. Enugu, Jock-Ken Publishers.

12. Mabogunje, A.L. (2000). Institutional radicalization, the state, and the development process in Africa. National Academy of Sciences Vol 97(25). 14007-14014.

13. Muoghalu, L.N. (1992). Rural Development in Nigeria: A Review of Previous Initiatives in Olisa, M.S.O. and Obiakwu J.T. (eds) Rural Development in Nigeria Dynamics and Strategies: Awka: Meklinks Publishers.

14. Oghojafor, B.E.A.; Alaneme, G.C. and Kuye, O.L. (2013). Indigenous Management Thoughts Concepts and Practices: The case of the Igbos' of Nigeria. Australian Journal of Business and Management Research Vol 3 No 1 08-15.

15. Okafor, F.C. (2005). Vicious Circle of Poverty: The Rural Poor on Toss. University of Benin Inaugural Lecture Series 79. University of Benin Press, Benin City.

16. Okafor, N. (2007). Law enforcement in post colonial Africa: Interfacing indigenous and English policing and English policing in Nigeria: International Police Executive Symposium Working Paper No 7. Available www.ipes.info. Accessed 26/7/14.

17. Onadapo, A.A. and Oladejo, M.O. (2011). Effectiveness of Millennium Development Goal Programmes on Entrepreneurial Development: An Appraisal of the Nigerian Experience. Journal of Emerging Trends in Economics and Management Sciences (JETEMS) 2(4) 310-319.

18. Otite, O. and Ogionwo, W. (2001). An Introduction to Sociological Studies, Ibadan, Heinemann.

19. Ottenberg, S. and Ottenberg, P. eds (1960). Cultures and Societies of Africa. Random House, New York.

20. Ray, M.A. (1992). Critical theory as a framework to enhance nursing science. Nursing Science Quarterly, 5(3) 98-101.

21. UNESCO (1982), Mexico City Declaration on Cultural Policies.

22. World Conference on Cultural Policies, Mexico City, 26 July - 6 August 1982.

$$
-375-
$$


23. Widjaja, M. (2001), Igbo culture, Igbo language and Enugu - Igboguide.org. http//www. igboguide.org/htm accessed 22-7-14.

24. Zimmerman, M.A. (2000). Empowerment theory: psychological, organizational, and community levels of analysis. In J.R.E. Seidmann (ed.) Handbook of Community Psychology. New York. Klumer Academic/Plenum.

25. Zoogah, D.B. (2009). Cultural value orientation, personality and motivational determinants of strategic leadership in Africa. International Journal of Leadership Studies 4(2). Pp. 63-56.

\title{
Преодоление парадигм \\ евроцентричного развития в Нигерии: \\ традиционные возрастные категории
}

\section{Эрнест Осас Юджиагбэ, Иджиома Юджиагбэ \\ Бенинский университет \\ Бенин, Нигерия}

\begin{abstract}
Правительство Нигерии находится в поиске устойчивого развития общества, что предполагает необходимость заглянуть внутрь общественного строя и заново исследовать и оценить наши коренные культурные практики для достижения желаемых результатов. $B$ статье дана оценка возрастным категориям коренного населения Нигерии, а также анализ возможного использования особенностей возрастных групп для достижения желаемого устойчивого развития. Благодаря культурным связям и общей иели, члены возрастных групп априори становятся инструментом для реализации трансформаций в отдаленных районах. Это связано с тем, что возрастные группы лучше знакомы с особенностями своих общин в отличие от посторонних людей и так называемых специалистов по развитию, поэтому необходимо задействовать разные возрастные группы и оснастить их необходимыми инструментами и техническими ноу-хау. Развитие отдаленных районов постепенно, но неумолимо станет реальностью ближайшего будущего.
\end{abstract}

Ключевые слова: развитие общества, культурное наследие, возрастные группь, общины, расширение прав и возможностей.

Научная специиальность: 22.00.00 - социологические науки. 